\title{
Multiple resistances of gastrointestinal nematodes to anthelmintic groups incattle of semiarid of Paraíba, Brazil
}

\author{
Wilson Wouflan Silva ${ }^{\mathrm{a}}$, Luciano José Bezerra Delfino ${ }^{\mathrm{b}}$, Maria do Carmo de Medeiros $^{\mathrm{b}}$, João Paulo da Silvab, \\ ${ }^{a}$ Unidade Acadêmica de Ciências Biológicas, Universidade Federal de Campina grande, Patos, 58708-110, Brasil. *wwouflan@gmail.com

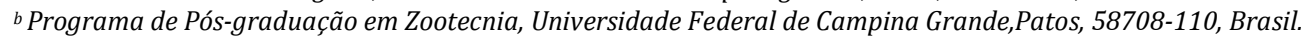

Recebido: 11abril 2017 / Aceito: 20 maio 2017 / Publicado online: 23 maio 2017

\begin{abstract}
The purpose of this research was to test the main anthelmintic drugs, such as Avermectins, Benzimidazoles, Imidazothiazoles, Tetrahydropyrimidines and Salicylanilides, used for the control of gastrointestinal nematodes in bovines on cattle ranches in the semiarid region of the state of Paraíba, Brazil. This study involved 40 animals per ranch, making a total of 200 animals of mixed breeds, varying in age from 12 to 36 months, with eggs per gram of faeces (EPG) $>500$. The anthelmintics were administered to the animals on day zero in a single dose, following the manufacturers' instructions. To determine the Fecal Egg-Count Reduction Test (RFEG), fecal samples were collected directly from the rectum on day zero and fourteen days after the beginning of the experiment. Among the various tested drugs, only Doramectin exhibited efficient performance (95.5\%), surpassing that of ivermectin $(81.5 \%)$. The results achieved with the other drugs were considered insufficient, since their efficiency was lower than $80 \%$. The highest parasitic load was presented by the genus Haemonchus spp., with an average of $87 \% \pm 0.06$ on day zero and $90 \pm 0.04 \%$ after 14 days.
\end{abstract}

Palavras-chave: Anthelmintic resistance, nematode, bovine, Haemonchus

\section{Múltiplas resistências de nematóides gastrintestinais aos grupos de anti- helmínticos em bovinos do Semiárido da Paraíba, Brasil}

\begin{abstract}
Resumo
Objetivo da pesquisa foi testar os principais anti-helmínticos utilizados para o controle de nematóides gastrintestinais de bovinos como as avermectinas, benzimidazóis, imidozotiazóis, tetrahidropirimidinas e, salicilanilidas em fazendas produtivas da mesorregião sertaneja do estado da Paraíba. Foram utilizados 40 bovinos por propriedade, totalizando 200 animais, com idades variando entre 12 e 36 meses, sem padrão racial definido, com OPG > 500. Os anti-helmínticos foram administrados aos animais no dia zero, em dose única, de acordo com a dosagem pré-estabelecida pelos fabricantes. Para a determinação da Redução da Contagem de Ovos Fecais (RCOF), amostras de fezes foram coletadas diretamente da ampola retal dos animais no dia zero e quatorze dias após o início do experimento. Dentre as drogas testadas, apenas a doramectina foi a única que apresentou resultado efetivo (955\%) superando ao da ivermectina (81,5\%). As demais drogas testadas apresentaram resultados considerados insuficientes, por apresentar eficiência inferior a 80\%. O gênero Haemonchus spp. foi o parasita que apresentou maior prevalência da carga parasitária com média de $87 \% \pm 0,06$ no dia zero e $90 \% \pm 0,04$ após 14 dias.
\end{abstract}

Key-words: Resistência anti-helmíntica, nematoda, bovinos, Haemonchus

\section{Introduction}

Gastrointestinal nematode infections in ruminants occur worldwide, with a higher prevalence in temperate regions whose climate favors the development of free-living stages of parasites (Martínez-Valladares et al., 2013). In the semiarid regions of northeastern Brazil, high production rates are observed in terms of gastrointestinal helminths, especially Haemonchus spp. Cobb (Silva et al. 1998). These diseases are responsible for major economic losses due to reduced food intake, weight loss, stunted growth, low fertility, decreased milk production, and high mortality rates in cases of parasitic infections (Lima et al. 2010).

In the effort to control helminthiasis, the indiscriminate use of drugs has resulted in populations of helminths selectively resistant to different chemical groups employed in the treatment of these animals (Shalaby, 2012). The bases used in the pharmacological treatment of helminths interfere mainly in energy production, muscle coordination, and microtubule dynamics, causing the destruction of parasites by starvation when their energy reserves are exhausted, or their expulsion due to paralysis (Brophy et al., 2012).

Researchers worldwide have reported parasite resistance 
to various pharmacological bases (Sarre et al., 2013), which is attributed to the incorrect use of anthelmintics to control infections in grazing animals or even due to a genetic character (Kohler, 2001). In Brazil, the most commonly used anthelmintics belong to three families: benzimidazoles, imidozotiazoles, and macrocyclic lactones. However, none of these drugs are effective for treating ruminant animals infected with gastrointestinal nematodes, especially Haemonchus contortus (Salgado and Santos, 2016). Few studies have investigated anthelmintic resistance in gastrointestinal nematodes of cattle in northeastern Brazil. From a technical standpoint, resistance is characterized by the failure of a drug to achieve 95\% efficacy (Terril et al., 2001). The antiparasitic compounds most commonly used in Brazil are Avermectins and Benzimidazoles.

The purpose of this study was to test the efficacy of anthelmintic drugs of the major groups of Benzimidazoles, Imidozotiazoles, Salicylanilides, Tetrahydropyrimidines and Avermectins in controlling gastrointestinal helminths of cattle in the semiarid region of the state of Paraíba in northeastern Brazil.

\section{Material and Methods}

\section{Characterization of the region}

This research was conducted on five cattle ranches in the Sertão region of Paraíba. The region's climate is semiarid, with a rainy season lasting from January to May, when more than $90 \%$ of the year's rainfall occurs, and a dry season from June to December. The average annual temperature is $30.6^{\circ} \mathrm{C}$ (minimum $28.7^{\circ} \mathrm{C}$ and maximum $32.5^{\circ} \mathrm{C}$ ), with only minor variations throughout the year. The vegetation belongs to the Caatinga biome, which is predominantly composed of shrub species such as Mimosa nigra Huber and cacti species such as Cereus jamacaru F. Hitter and Pilocereus gounellei Lem. (Vilela et al., 2008).

\section{Animals}

This study involved 200 animals of mixed breeds, 40 from each ranch, ranging in age from 12 to 36 months, with EPG > 500 (Eggs Per Gram of feces). The 40 animals on each ranch were divided into four groups of ten animals, two groups treated with anthelmintics and the other two serving as their respective control groups. Each group contained five males and five females. The anthelmintic groups used in this study were Benzimidazoles (albendazole and oxfendazole), Imidazothiazoles (tetramisole and levamisole), Salicylanilides (closantel and disophenol), and Avermectins (ivermectin and doramectin). Each chemical compound was selected randomly to be administered on a ranch; the Avermectins were administered subcutaneously and the other groups orally.

After the random selection, the anthelmintics were administered to the animals in a single dose on day zero, following the manufacturers' instructions. To determine the Fecal Egg Count Reduction (FECR), fecal samples were collected directly from the rectum on day zero and fourteen days after the beginning of the experiment. On day zero, sampling was performed three times: at 6:00 a.m., at noon, and at 6:00 p.m. The samples were identified, stored on ice in polystyrene boxes, and sent to the Laboratory of Parasitic Diseases of Farm Animals (LDPAD) at the Federal University of Campina Grande in Patos, state of Paraíba, where the EPG test was performed according Gordon and Whitlock, 1939 and stool testing according to Roberts and O’Sullivan (1950).

The effectiveness of the drugs was evaluated based on the Technical Regulation of Directive No. 48/1997 of the Brazilian Ministry of Agriculture, Livestock and Food Supply (MAPA) for chemical substances with antiparasitic activity. The evaluation was based on the following parasite reduction criteria: Highly effective $=>98 \%$ reduction; Effective $=90-98 \%$ reduction; Moderately effective $=80$ $89 \%$ reduction; and Insufficiently active $=<80 \%$, unrecordable MAPA (1997).

\section{Statistical analysis}

The mean of the EPG of the three stool samples from each animal was calculated, after which the average of each treated group after 14 days was calculated (EPGday14) and compared with the EPG on day zero (EPGday0). The Fecal Egg-Count Reduction Test (RFEG) was determined using the formula: $\mathrm{FECR}=[1-(\mathrm{EPG}$ day14/EPGday0) $] \times 100$. The data were then subjected to the t-test for independent samples with a significance level of 0.05 . The EPG values were analyzed by $\log$ transformation $(x+1)$, although they are shown here as arithmetic means of the non-transformed values. The analyses were performed using BioEstat version 5.0 software Ayres et al. (2003).

\section{Animal ethics}

This study was submitted to the Ethics Committee on Animal use in Research (CEUA) of the Federal University of Campina Grande, Center for Rural Health and Technology at the protocol's number CEUA n ${ }^{\circ} 138 / 2014$.

\section{Results and Discussion}

Among the tested drugs, only Doramectin showed satisfactory results $(95.5 \%)$, surpassing that of Ivermectin (81.5\%; Table 1).

An analysis of the various species that make up the parasite load indicates that the genus Haemonchus spp. showed the highest prevalence, even after treatment with various anthelmintics (Table 2).

To results seen in Table 1, in Brazil similar results have been reported by Lopes et al. (2013) in the treatment of gastrointestinal helminths of cattle in Jaboticabal, with $95 \%$ efficiency.

To results seen in Table 1, in Brazil similar results have been reported by Lopes et al. (2013) in the treatment of gastrointestinal helminths of cattle in Jaboticabal, with $95 \%$ efficiency.

The other tested drugs presented results considered insufficient, since their efficiency was lower than $80 \%$ (MAPA, 1997), with albendazole presenting the lowest parasite reduction rate $(20.3 \%)$. 
Table 1. Mean ofeggs per gram of faeces (EPG) and FECR cattle subjected to anthelmintic treatment in semiarid Paraiba.

\begin{tabular}{|c|c|c|c|}
\hline Group & Day 0 & Day 10 & RCOF \\
\hline \multicolumn{4}{|c|}{ Avermectines } \\
\hline Ivermectin & $1810 \pm 350^{\mathrm{a}}$ & $240 \pm 60^{\mathrm{b}}$ & $81,6 \%$ \\
\hline Control & $1280 \pm 280^{\mathrm{b}}$ & $1305 \pm 300^{\mathrm{a}}$ & - \\
\hline Doramectin & $1500 \pm 310^{a}$ & $50 \pm 10^{b}$ & $95,5 \%$ \\
\hline Control & $1050 \pm 250^{\mathrm{b}}$ & $1100 \pm 210^{\mathrm{a}}$ & - \\
\hline \multicolumn{4}{|c|}{ Benzimidazoles } \\
\hline Albendazole & $700 \pm 200^{\mathrm{a}}$ & $470 \pm 90^{\mathrm{a}}$ & $20,3 \%$ \\
\hline Control & $610 \pm 110^{\mathrm{a}}$ & $590 \pm 100^{\mathrm{a}}$ & - \\
\hline Oxfendazole & $770 \pm 100^{a}$ & $480 \pm 90^{\mathrm{b}}$ & $28,7 \%$ \\
\hline Control & $660 \pm 75^{\mathrm{a}}$ & $673 \pm 80^{\mathrm{a}}$ & - \\
\hline \multicolumn{4}{|c|}{ Imidazotiazoles } \\
\hline Levamisole & $1270 \pm 270^{\mathrm{b}}$ & $480 \pm 90^{\mathrm{b}}$ & $58,3 \%$ \\
\hline Control & $1700 \pm 290^{a}$ & $1150 \pm 120^{a}$ & - \\
\hline Tetramisole & $1283^{\mathrm{a}}$ & $530^{\mathrm{b}}$ & $56,6 \%$ \\
\hline Control & $1170^{\mathrm{a}}$ & $1220^{\mathrm{a}}$ & - \\
\hline \multicolumn{4}{|c|}{ Salicilanilides } \\
\hline Closantel & $1100 \pm 270^{\mathrm{a}}$ & $700 \pm 190^{b}$ & 45,45 \\
\hline Control & $1500 \pm 310^{a}$ & $1350 \pm 270$ & - \\
\hline Disophenol & $970 \pm 260^{a}$ & $780 \pm 270^{\mathrm{b}}$ & $65,6 \%$ \\
\hline Control & $960 \pm 280^{\mathrm{a}}$ & $770 \pm 200^{\mathrm{a}}$ & - \\
\hline \multicolumn{4}{|c|}{ Tetrahydropirimidines } \\
\hline Pyrantel & $1780 \pm 320^{\mathrm{a}}$ & $1190 \pm 195^{\mathrm{b}}$ & $66,78 \%$ \\
\hline Control & $660 \pm 190^{a}$ & $673 \pm 270^{\mathrm{a}}$ & - \\
\hline Morantel & $1770 \pm 255^{\mathrm{a}}$ & $1200 \pm 200^{\mathrm{b}}$ & $56,4 \%$ \\
\hline Control & $960 \pm 200^{\mathrm{a}}$ & $873 \pm 180^{\mathrm{a}}$ & - \\
\hline $\begin{array}{l}\text { Values for } \\
\text { followed by }\end{array}$ & groups and $\mathrm{t}$ & $r$ respective & les. RCO \\
\hline
\end{tabular}

These results indicate that the gastrointestinal nematodes were resistant to virtually all the anthelmintic drugs normally applied to cattle in the state of Paraíba. According to Shalaby (2013), such multiple resistance has been observed in regions where multiple anthelmintic treatments are applied during the year. Another important factor is the pharmacokinetic behavior of each formulation, which may be selective for the development of parasitic resistance if it persists as a subdosage in the animal's body over a long period of time (Vercruysse et al., 2011).

The low efficiency of anthelmintics that are not normally used may be of genetic origin, according to the theory of evolution that explains the emergence of nematode strains resistant to anthelmintics, which pass on their resistance genes to their offspring (Stear et al., 2007). Nematodes are able to develop anthelmintic resistance within five to eight generations after the introduction of a new chemical group (Grant, 2001), and the lifespan of each generation of gastrointestinal nematodes of ruminants is approximately one year (Prichard et al., 1980).

The composition of parasite burden detected in this study table 2, was identical the results observation by Silva et al. (2003) that using tracers goats, observed that this genus was prevalent in this region throughout the year in both the dry and rainy seasons.
Table 2. Meanpercentage of genera of gastrointestinal helminths of cattle subjected to anthelmintic treatment in semiarid Paraiba.

\begin{tabular}{lcccccc}
\hline \multirow{2}{*}{ Group } & \multicolumn{3}{c}{ Day 0} & \multicolumn{3}{c}{ Day 10} \\
\cline { 2 - 7 } Ivermectin & H & T & O & H & T & O \\
\hline Control & 82 & 5 & 3 & 94 & 2 & 4 \\
Doramectin & 83 & 8 & 5 & 90 & 7 & 3 \\
Control & 79 & 20 & 1 & 85 & 13 & 2 \\
\hline Albendazole & 75 & 19 & 6 & 82 & 10 & 8 \\
Control & 86 & 10 & 4 & 92 & 8 & 0 \\
\hline Oxfendazole & 85 & 13 & 2 & 90 & 10 & 0 \\
Control & 93 & 7 & 0 & 86 & 12 & 2 \\
\hline Levamisole & 97 & 0 & 3 & 93 & 6 & 1 \\
Control & 87 & 10 & 3 & 91 & 5 & 4 \\
\hline Tetramisole & 90 & 7 & 3 & 96 & 6 & 0 \\
Control & 89 & 11 & 0 & 88 & 15 & 1 \\
\hline Closantel & 83 & 17 & 0 & 80 & 16 & 5 \\
Control & 79 & 20 & 1 & 87 & 17 & 2 \\
\hline Disophenol & 75 & 19 & 6 & 86 & 10 & 4 \\
Control & 86 & 10 & 4 & 90 & 9 & 1 \\
\hline Pyrantel & 85 & 13 & 2 & 80 & 12 & 8 \\
Control & 93 & 7 & 0 & 86 & 15 & 2 \\
\hline Morantel & 90 & 8 & 3 & 93 & 4 & 3 \\
Control & 80 & 13 & 8 & 90 & 4 & 6 \\
\hline
\end{tabular}

H: Haemonchusssp.; T: Trichostrongylusssp.;

O: Oesophagostomumssp.

The high prevalence of the genus Haemonchus spp. in the groups of treated animals indicates its resistance to the drugs used in this study.

Similar results have been reported by researchers around the world (McMahon et al., 2013; Cezar et al., 2010), especially in tropical areas where multiple treatments per year are necessary, although (Coles et al., 2006) reports the development of anthelmintic resistance even when only two or three treatments are applied during the year.

This study demonstrated that worming as the only form of parasite control is not effective, in view of the multiple anthelmintic resistance of gastrointestinal nematodes of cattle in the interior of the state of Paraiba, Brazil. Complementary mechanisms of management are therefore needed to prevent this resistance from increasing.

\section{Conclusion}

Only group of bovines treated with Avermectins presented satisfactory results for parasitic control in semiarid Paraiba. Other pharmacology groups with benzimidazoles, imidazothiazoles, salicylanilides and tetrahydropyrimidines presented results that indicating parasitic resistance.

\section{Referências}

Ayres, M. 2013. Aplicações estatísticas nas áreas de ciências biológicas. Sociedade Civil Mamirauá, Brasília CNPq: Belém, 290p.

Brophy, P.M.; Mackintosh, N.; Morphew, R.M. 2012. Anthelmintic metabolism in parasitic helminths: proteomic insights Parasitology 
Brophy, Peter. 139(9): 1205 -1217.

Cezar, A.S.; Vogel, F.S.F.; Sangioni, L.A.; Antonello, A.M.; Camillo, G.; Toscan, G.; Araújo, L.O. 2010. Ação anti-helmíntica de diferentes formulações de lactonas macrocíclicas em cepas resistentes de nematódeos de bovinos. Pesquisa Veterinária Brasileira, 30(7): 523-528.

Coles G.C.; Jackson, F.; Pomroy, W.E.; Prichard, R.K.; von SamsonHimmelstjerna, G.; Silvestre, A.; Taylor, M.A.; Vercruysse, J. 2006. The detection of anthelmintic resistance in nematodes of veterinary importance. Veterinary Parasitology. 136(3-4): 167-185.

Gordon, H.M.; Whitlock, H.V. 1939. A new technique for counting nematode eggs in sheep faeces. Journal Council Science Industry Research Australy. 12: 50-52.

Grant, W. 2001. Population genetics and drug resistance in nematode parasites. Trends in Parasitology,17(9): 410.

Shalaby, H.A. 2013. Anthelmintics Resistance; How to Overcome it. Iranian Journal Parasitology, 8(1): 18-32.

Köhler, P. 2001. The biochemical basis of anthelmintic action and resistance. International Journal Parasitology, 31:336-345.

Famularo, M.R.; Fernández-Pato, N.; Castañon-Ordoñez, L.; Rojo-Vázquez, F.A. 2013. The present status of anthelmintic resistance in gastrointestinal nematode infections of sheep in the northwest of Spain by in vivo and in vitro techniques. Veterinary Parasitology, 191: 177181.

Lima, A.M.; Soares, A.M.; Lima, N.L.; Mota, R.M.S.; Maciel, B.L.L.; Kvalsund, M.P.; Barrett, L.J.; Fitzgerald, R.P.; Blaner, W.S.; Guerrant, R.L. 2010. Vitamin A supplementation effects on intestinal barrier function, growth, total parasitic and specific Giardia spp. infections in Brazilian children: a prospective randomized, double-blind, placebocontrolled trial. Journal of Pediatric Gastroenterology and Nutrition, 50(3): 309-315.

Lopes, W.D.Z; Santos, T.R; Sakamoto, C.A.M.; Lima, R.C.A.; Valarelli R.L.; Paiva, P.; Costa, A.J. 2013. Persistent efficacy of 3.5\% doramectin compared to $3.15 \%$ ivermectin against. Research in Veterinary Science 94(2): 290-294.

Martínez-Valladares M.; Martínez-Pérez, J.M.; Robles-Pérez, D.; CorderoPérez, C.; McMahon C.; Bartley, D.J.; Edgar, H.W.J.; Ellison, S.E.; Barley, J.P.; Malone, F.E.; Hanna, R.E.B.; Brennan, G.P.; Fairweather, I. 2013. Anthelmintic resistance in Northern Ireland (I): Prevalence of resistance in ovine gastrointestinal nematodes, as determined through faecal egg count reduction testing. Veterinary Parasitology, 195(1-2): 122-130.

McMahona, C.; Bartleyb, D.J.; Edgarc, H.W.J.; Ellisona, S.E.; Barleyc, J.P.; Malonec, F.E.; Hannac, R.E.B; Brennana, G.P.; Fairweathera, I. Anthelmintic resistance in Northern Ireland (I): Prevalence of resistance in ovine gastrointestinal nematodes, as determined through faecal egg count reduction testing. Veterinary Parasitology, 195(1-2): 122-130.

Ministério da Agricultura e Abastecimento. Regulamento Técnico para Licenciamento e/ou Renovação de Licença de Produtos Antiparasitários de Uso Veterinário. 1997. Portaria $\mathrm{n}^{\circ} 48$, de 12 de maio de 1997. Diário Oficial da União de 16/05/1997. Seção 1, Página 10165.

Prichard, R.K.; Hall, C.A.; Kelly, I.D.; Martin, I.C.A.; Donald, A.D. 1980. The problem of resistance in nematodes. Australian Veterinary Journal, 56: $239-251$

Roberts, F.H.S.; O'sullivan, J.P. 1950. Methods of egg counts and laval cultures for strongyles infesting the gastrointestinal tract of cattle. Australian Journal Agriculture Research, 1: 99-102.

Sarre, C.; Claerebout, E.; Vercruysse, J.; Levecke, B.; P. Geldhof, P.; Pardon, B.; Alvinerie, M.; Sutra, J.F.; Geurden, T. 2012. Geurden. Doramectin resistance in Haemonchus contortus on an alpaca farm in Belgium. Veterinary Parasitology, 185: 346-351.

Salgado, J.A.; Santos, C.P. 2016. Overview of anthelmintic resistance of gastrointestinal nematodes of small ruminants in Brazil. Revista Brasileira de Parasitologia Veterinária, 25(1): 3-17.

Stear, M.J.; Fitton, L.; Innocent, G.T.; Murphy, L.K.R.; Matthews, L. 2007. The dynamic influence of genetic variation on the susceptibility of sheep to gastrointestinal nematode infection. Journal Real Socity Interface, 4(16): 1742-5662.

Silva, W.W, Bevilaqua, C.M.; Costa, A.L. 1998. Natural evolution of gastrointestinal nematodes in goats (Capra hircus) in the semi-arid ecosystem of the Paraíba backwoods, northeastern Brazil. Veterinary
Parasitology, 80(1): 47-52.

Terril, T.H.; Kaplan, R.M.; Larsen, M.; Samples, O.M.; Millerf, J.E.; Gelaye, S. 2001. Anthelmintic resistance on goat farms in Georgia: efficacy of anthelmintics against gastrointestinal nematodes in two selected goat herds. Veterinary Parasitology, 97(4): 261-268.

Vercruysse, J.; Albonico M.B.; Behnkec, J.M.; Kotze, A.C.; Pricharde, R.K.; McCarthyf, J.S.; Montresor, A.; Leveckea B. 2011. Is anthelmintic resistance a concern for the control of human soiltransmitted helminthes. International Journal for Parasitology: Drugs and Drug Resistance, 1(1): 14-27.

Vilela, V.L.R.; Solano, G.B.; Araújo, M.M.; Sousa, R.V.R.; Silva, W.A.S.; Feitosa, T.F.; Athayde, A.C.R. 2008. Ensaios preliminares para a validação do Método FAMACHA® em condições de semiárido paraibano. Revista Brasileira de Parasitologia Veterinaria, 17(supl. 1): 164-167. 